Article

\title{
Callus Induction from Root Fragments of Falcataria moluccana
}

\section{Plantlets}

\author{
Asri Putri ${ }^{1 *}$, ILG Nurtjahjaningsih ${ }^{2}$, Istiana Prihatini , Mohammad Na'iem ${ }^{3}$, Sapto Indrioko ${ }^{5}$, Sri Rahayu ${ }^{6}$ \\ 1 Ministry of Environment and Forestry of Indonesia; asriip.ap@gmail.com \\ 2 Ministry of Environment and Forestry of Indonesia; Iluh_nc@yahoo.com \\ 3 Ministry of Environment and Forestry of Indonesia; istiana.prihatini@biotifor.or.id \\ 4 Faculty of Forestry, Gadjah Mada University, Yogyakarta, Indonesia; mnaiem@ugm.ac.id \\ 5 Faculty of Forestry, Gadjah Mada University, Yogyakarta, Indonesia; sindrioko@ugm.ac.id \\ 6 Faculty of Forestry, Gadjah Mada University, Yogyakarta, Indonesia; tatarahayu@yahoo.com \\ * Correspondence author: +6281559728514
}

\begin{abstract}
Callus induction of F. moluccana (sengon) was still an obstacle to indirect organogenesis regeneration. The purpose of the study was to determine the callus induction formation from root fragments of F. moluccana plantlets. Primary explants (fragments of roots) were cultivated on MS induction basal media and three concentration combination of PGRs (BAP and NAA): $0.5 \mathrm{ml} / 1$ BAP; 0,1 ml/l NAA (single PGR); and combination of $0.5 \mathrm{ml} / 1 \mathrm{BAP}+0.1 \mathrm{ml} / 1 \mathrm{NAA}$ (double PGR). When roots were used as explants, high formation rates of callus (more than $70 \%$ ) were obtained. Highest formation rates of callus were in NAA added at all clones (12 clones), then BAP added (7 clones) and BAP + NAA added (5 clones). The results indicated that BAP and NAA concentrations used in the media were influence the producing callus and affect the amount of callus produced from roots of sengon. The addition of NAA also gives higher callus proliferation results than the addition of $\mathrm{BAP}$ or the addition of a combination of the two hormones. The results indicated that BAP and NAA concentrations used in the media were influence the producing callus and affect the amount of callus produced from roots of sengon.
\end{abstract}

Keywords: PGRs, callus induction, indirect organogenesis

\section{Introduction}

Falcataria moluccana (Miq.) Barneby \& J. W. Grimes belong to the Fabaceae family, also known as sengon in Indonesia, is native to Indonesia, Papua New Guinea, and the Solomon Islands [1](Larsen, 1993). The wood of this species has been used for light-construction materials, veneer, particle board, and pulp. One of the forest-breeding programmed is to develop selected clones of valuable woody trees. To enhance the efficiency and success rate of this breeding programmed, more rapid and costeffective methods are needed. Conventional breeding methods are often constrained by the long reproductive cycles and by the difficulty in achieving significant improvements to complex traits such as wood properties, disease and pest control, and tolerance to abiotic stress [2]. Tissue culture has a potential to solve these problems. However, only a few reports on tissue culture of sengon are available and all of the research use the generative material from unselected seeds for explants $[2,3]$ and it is not clear 
whether there are multiple mechanisms of callus initiation in different species and in different organs [4].

The ability to form callus in tissue culture varies in diverse species. Not all somatic cells are competent to form callus; only a group of adult stem cells, i.e. regeneration-competent cells, may initiate regeneration [5]. In Arabidopsis, the pro-cambium and some vascular parenchyma cells in leaves and the xylem-pole pericycle cells in roots may serve as regeneration competent cells, while in rice the bundle sheath and some immature vascular cells in leaves and the phloem-pole pericycle cells in roots may serve as regeneration-competent cells (6). These competent cells are responsible not only for callus initiation but also for root primordial initiation during adventitious root (AR) or lateral root (LR) formation [5]. There have been few reports on the regeneration of plants root culture, as these explants have been found to be recalcitrant with respect to the formation of morphogenic callus. If their recalcitrant nature could be overcome, roots would be an ideal explant source for obtaining regenerated plants. Roots are plentiful, available at all times, are easy to excise and are also a well-defined source of meristematic tissue. [7] also stated that the un-pigmented nature of root protoplasts made them ideal for use as markers in protoplast fusion work. Due to the uniqueness of these legume roots, callus culture research has never been conducted using roots as explant material.

An important factor reported in several species with regard to callus induction is the explants type, example: nodal segmen of medicinal tree Premna serratifolia L. [8], inter- nodal segments of T. grandis L.f. [9] and young leaves and shoot tips of L. camara (Saxena et al., 2013). In addition, there was variation in the plant growth regulators used to induce callus, only indole acetic acid (IAA) [8], BA (Srinivasan et al., 2012) and 2,4-dichlorophenoxyacetic acid (2,4-D) (Saxena et al., 2013) as well as a combination of BAP and NAA [8].

In the present study, in vitro culture of root fragment callus induction from selected vegetative plantlet material were investigated for the establishment of efficient micro propagation protocol of sengon, multi purposes of tropical fast-growing tree, for mass propagation.

\section{Materials and Methods}

The study was located at the tissue culture laboratory in Centre for Forest Biotechnology and Tree Improvement, Yogyakarta, Indonesia. Research observations were carried out for 12 months, from January 2018 to January 2019. The equipment used in this study conformed to tissue culture laboratory standards.

\section{Plantlet preparation}

The selected sengon plantlets were obtained from Balai Besar Penelitian dan Pengembangan Bioteknologi dan Pemuliaan Tanaman Hutan (BBPPBPTH), Yogyakarta. Selection of plantlets based on the sprouting ability from one explant in vitro that was carried out in previous research conducted by Putri, 2017 [10]. The source of the plantlets was vegetatively from 3 clones sengon micro propagation. Axenic culture in MS (Murashige \& Skoog) [11] basal media supplemented with BAP (6- 
Benzylaminopurine) $1 \mathrm{ml} / \mathrm{l}$, NAA (1-Naphthaleneacetic acid) $1 \mathrm{ml} / \mathrm{l}, 3 \%$ sucrose and $0.2 \%$ agar, whose $\mathrm{pH}$ was adjusted to $5.7 \pm 0.1$ was used as sources of root fragment for callus induction.

\section{Callus induction}

The cutting of the roots as explants from the plantlets was aseptically carried out in laminar air flow (LAF). Root pieces were directly transferred to callus media. Each explant was cultured in MS media with a combination of a cytokinin (BAP) and an auxin (NAA) at different concentrations (1000 ppm solution each): $0.5 \mathrm{ml} / \mathrm{l} \mathrm{BAP}$; $0.1 \mathrm{ml} / 1 \mathrm{NAA}$ (single PGR); and combination of $0.5 \mathrm{ml} / 1 \mathrm{BAP}+0.1 \mathrm{ml} / 1 \mathrm{NAA}$ (double PGR), cultured in 16 hours a light photoperiod $(50 \sim 70 \mu \mathrm{mol} / \mathrm{m} 2 / \mathrm{s})$ and sub-cultured every month until 6 months of incubation. The effect of the hormone combination was tested on 20 replications of the explants from 3 clones for each treatment. The callus formation rate was recorded after 6 weeks of culturing. The following equation was used for determining for callus formation rate:

Callus formation rate $=$ Number of roots with callus $\times 100 \%$

Number of incubated roots

After 6 months incubation, formation rate, callus proliferation and callus color were observed. The overall study was carried out for 12 months at tissue culture laboratory.

\section{Results}

The roots of plantlet used as the material for this study, one of the successes of sengon tissue culture that Putri [10] has done in previous research, were derived from vegetative micro cutting (Figure 1.A). These plantlets were sub-cultured 3 times, 4 weeks each sub-culture since the transfer of explants.
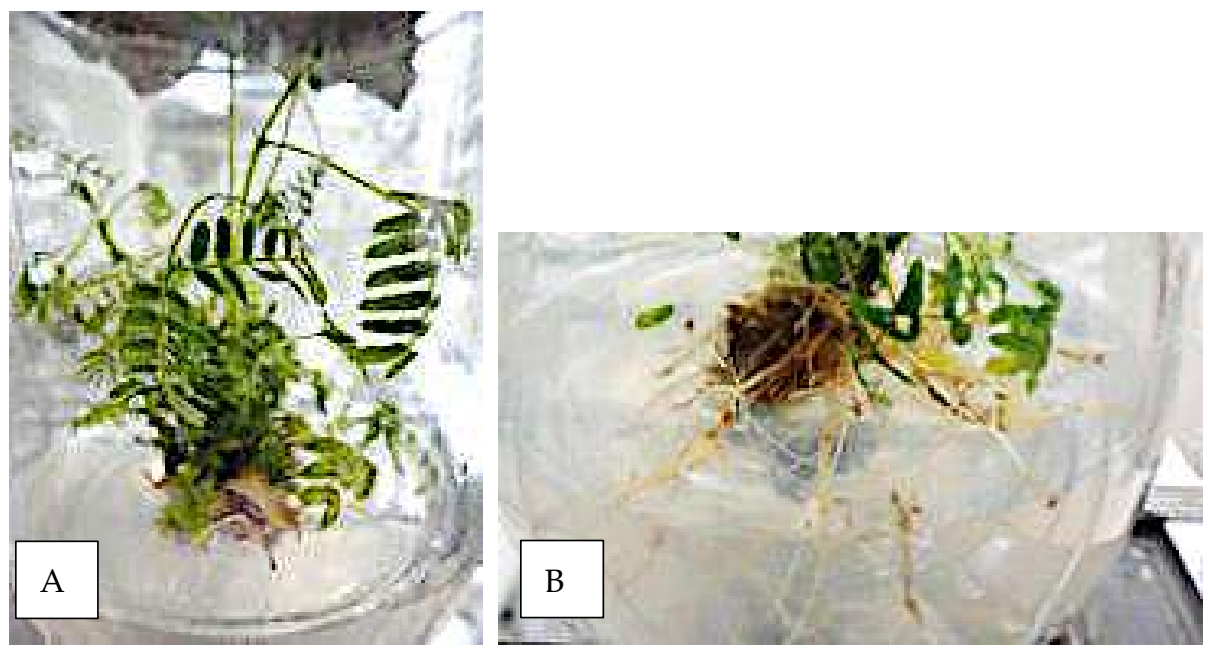

Figure 1. Sengon micro cutting plantlets (A), and roots from the plantlet used as the material for this study (B) (documentation by Putri, 2018) 
Table 1 shows the formation rate, callus proliferation and callus color of sengon induced from 3 clones of explant in MS media with a combination of single and double PGRs after 6 weeks of culture.

Table 1. Formation rate, callus proliferation and color of callus induced from 3 sengon clones of explant in MS media with single and double PGRs after 6 weeks of culture.

\begin{tabular}{|c|c|c|c|c|c|c|c|c|c|}
\hline \multirow[t]{2}{*}{ Clones } & \multicolumn{3}{|c|}{ BAP } & \multicolumn{3}{|c|}{ NAA } & \multicolumn{3}{|c|}{ BAP \& NAA } \\
\hline & $\begin{array}{l}\text { FR } \\
(\%)\end{array}$ & $\mathrm{P}$ & $\mathrm{C}$ & $\begin{array}{l}\text { FR } \\
(\%)\end{array}$ & $\mathrm{P}$ & $\mathrm{C}$ & $\begin{array}{l}\text { FR } \\
(\%)\end{array}$ & $\mathrm{P}$ & $\mathrm{C}$ \\
\hline \multicolumn{10}{|c|}{ Clones 1} \\
\hline C.1.1 & 100 & + & B & 100 & ++ & BG & 90 & + & B \\
\hline C.1.2 & 100 & ++ & $\mathrm{BB}$ & 100 & ++ & BW & 90 & + & B \\
\hline C.1.3 & 80 & ++ & B & 100 & ++ & BW & 100 & + & B \\
\hline C.1.4 & 100 & ++ & $\mathrm{B}$ & 100 & +++ & BY & 70 & ++ & G \\
\hline C.1.5 & 85 & + & B & 100 & ++ & BG & 70 & & $\mathrm{BB}$ \\
\hline \multicolumn{10}{|c|}{ Clones 2} \\
\hline C.2.1 & 80 & + & B & 100 & ++ & WG & 100 & + & $\mathrm{B}$ \\
\hline C.2.2 & 100 & ++ & B & 90 & +++ & BG & 100 & + & B \\
\hline C.2.3 & 80 & + & B & 100 & ++ & $\mathrm{B}$ & 80 & ++ & BW \\
\hline C. 2.4 & 70 & +++ & B & 80 & ++ & WG & 90 & ++ & BW \\
\hline C.2.5 & 70 & ++ & B & 100 & +++ & BG & 90 & + & B \\
\hline \multicolumn{10}{|c|}{ Clones 3} \\
\hline C.3.1 & 100 & ++ & $\mathrm{B}$ & 100 & ++ & $\mathrm{B}$ & 70 & + & G \\
\hline C.3.2 & 70 & + & $\mathrm{B}$ & 100 & ++ & BY & 70 & + & $\mathrm{B}$ \\
\hline C.3.3 & 70 & ++ & $\mathrm{BB}$ & 100 & + & $\mathrm{BW}$ & 100 & ++ & B \\
\hline C.3.4 & 100 & ++ & $\mathrm{BW}$ & 90 & + & $\mathrm{BB}$ & 100 & ++ & $\mathrm{BW}$ \\
\hline C.3.5 & 100 & +++ & BW & 100 & ++ & B & 70 & + & B \\
\hline
\end{tabular}

Note: Formation rate (FR), Callus proliferation (P): -, no callusing; +, low; ++, moderate; +++, high. Callus color (C): B, brown; BG, brownish green; BB, brownish black; BW, brownish white; BY, brownish yellow; G, grey; BW, brownish white; WG, whitish green. Data were recorded after 6 weeks of culture. MS medium was used as a basal medium.

During experiment we observed formation of seven callus color (Figure 2). BAP has a browner (B) effect on callus, followed by NAA, while the effect of the combination of BAP and NAA is more diverse in color and all textures were friable and different stages. 

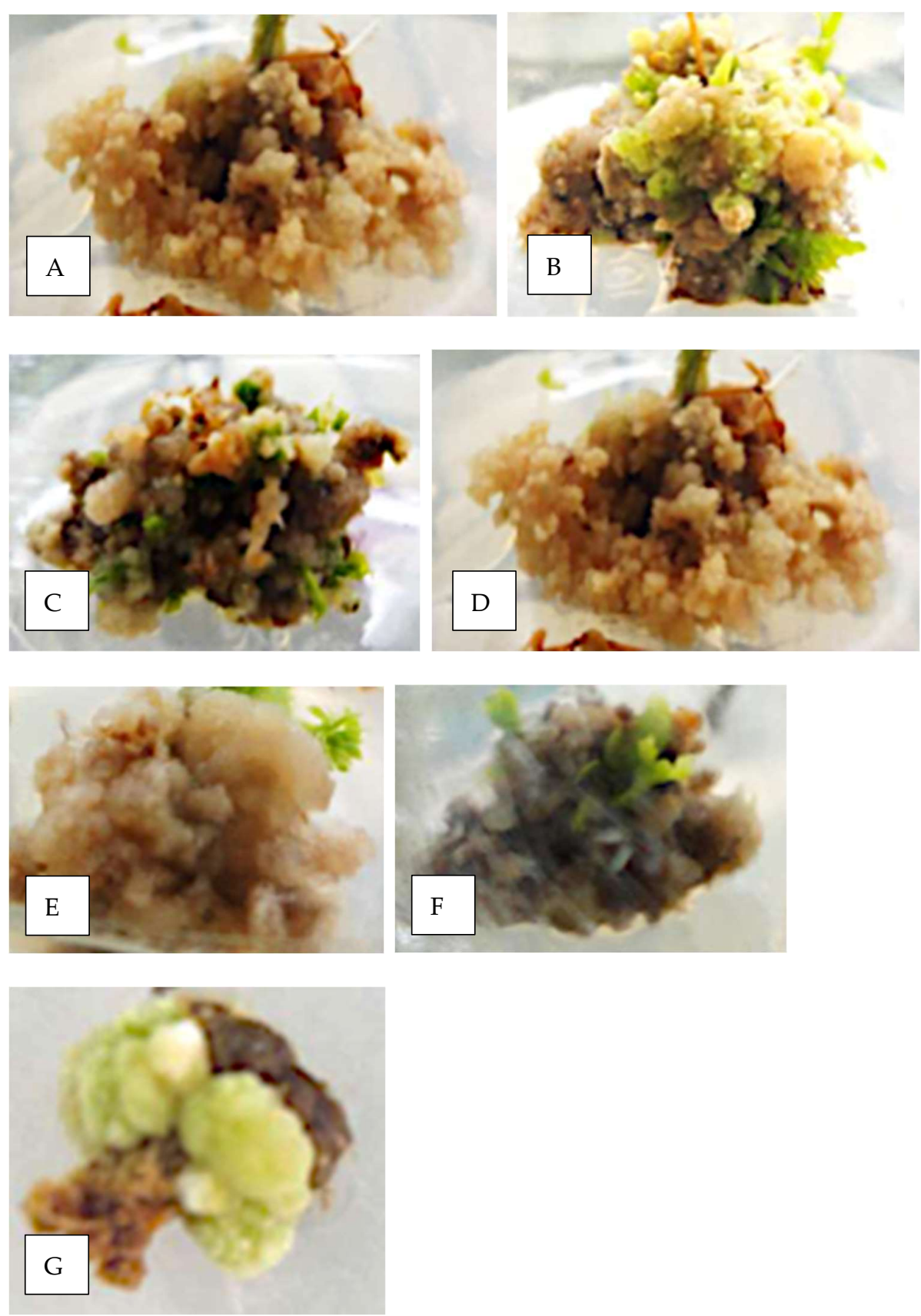

Figure 2. The effect of PGR on various callus colors, brown (A), brownish green (B), brownish black $(C)$, brownish yellow $(D)$; brownish white $(E)$, grey $(F)$; and whitish green (G), (documentation by Putri, 2018)

Microscopic observation showed callus development at week 4 and week 6 of incubation (Figure 3). Globular friable callus develops to a larger size to form the next callus phase. PGRs stimulated cell elongation by increasing of plasticity of the cell wall to become loose, causing water to easily flow to the inner cell by osmosis, causing the cell to become elongated [12]. 

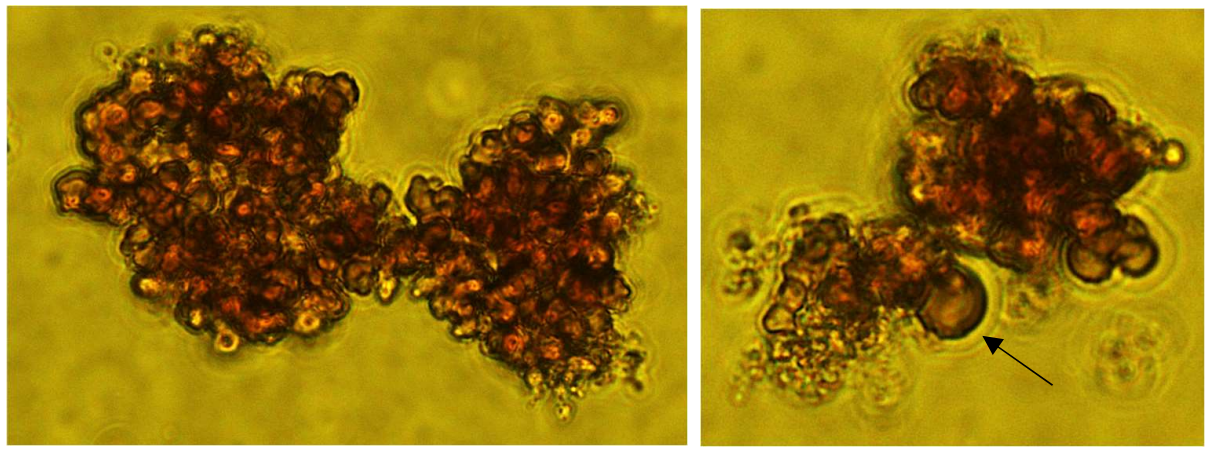

Figure 3. Microscopic development of calluses at $4^{\text {th }}$ week incubation (A) and at $6^{\text {th }}$ week incubation (B), globular friable callus develops to a larger size (an arrow), (x 100 microscop magnification ) (documentation by Putri, 2018).

\section{Discussion}

Macro and micro vegetative propagation of sengon has never been successful before, one of the obstacles to the propagation of macro sengon is that it does not form roots, which occurs in vitro (Figure 1.B) [10]. One thing that affects the success of sengon micro cutting is the availability of nutrients and controlled abiotic and biotic environmental conditions. In Table 1 shows the formation rate, callus proliferation and color of callus induced from 3 clones of explant in MS media with a combination of single and double PGRs after 6 weeks of culture. When roots were used as explants, high formation rates of callus (more than $70 \%$ ) were obtained. Highest formation rates of callus were NAA added in all clones (12 clones), then BAP added (7 clones) and $\mathrm{BAP}+\mathrm{NAA}$ added (5 clones). The results indicated that BAP and NAA concentrations used in the media were influence the producing callus and affect the amount of callus produced from roots of sengon.

The addition of NAA also gives higher callus proliferation results than the addition of BAP or the addition of a combination of the two hormones. Auxins (NAA) have many effects and can modulate diverse processes and tropic responses (reviewed in [13]. In in vitro culture, exogenous auxins are assumed to orientate developmental pathways and to favour either callogenesis or rhizogenesis according to the concentration [14]. However, there are few comparative detailed studies of the effects of changes in auxin concentrations during callogenesis and rhizogenesis. Although, NAA is rarely used in indirect somatic embryogenesis processes, this hormone has been used to study the switch between distinct organogenic pathways [5]. Table 1 also shows that of the 3 sengon clones tested had no effect on formation rate, callus proliferation and color of callus.

There have been few reports on the regeneration of plants from root cultures of sengon, as these explants have been found to be recalcitrant with respect to the formation of morphogenic callus if their recalcitrant nature could be overcome, roots would be an ideal explant source for obtaining regenerated plants. Roots are plentiful, available at all times, are easy to excise and are also a well- defined source of meristematic tissue. [16] also stated that the unpigmented nature of root protoplasts made them ideal for use as markers in protoplast fusion work.

Figure 2 shows that the wall cell has not reached lignification yet because of friable calluses contain much water, and the group of cells can be easily separated from the others. The callus texture from the explant can be distinguished as friable 
and non-friable. The non-friable callus has compact and tight cells that are difficult to separate. In contrast, a friable callus from an explant has loose cell interaction that is easily detached using tweezers. The resulting color variations might be due to the diverse types of growth regulators, the difference in growth regulator concentration, but not the clones of. Compared to single PGR, a combination of auxin and cytokinin resulted in a callus color that was greener, caused by cytokinin, which tends to promote chlorophyll formation [17] . According to [18], various callus color conditions could be caused by the pigmentation, the influence of light, and the plant parts used as the source explant. Table 1 also shows that of the 3 sengon clones tested had no effect on formation rate, callus proliferation and color of callus.

Callogenesis is the initial response, characterized by the formation of the callus, which starts from the edge of the explant (wounded part) at the top and bottom of the sengon roots that has direct contact with the medium. The callus is formed faster and bigger size on the part that has direct contact with the media (Figure 3). This is probably related to the process of nutrient uptake in the medium by the explant. The appearance of the callus on the wounded part might be caused by the excitement of the tissue on the explant to cover the wound. [19] stated that the cell division that leads to the callus formation occurs from the injuries and both the natural and artificial hormone supply from the outside into the explant. Light is an external factor that influences callus formation. The color change that exists in the callus was because of pigment, nutrients, and environmental factors, such as light. White light could induce callus formation and organogenesis in the plant tissue. A callus that has yellowish green and green color was formed with the addition of cytokinin (BAP). The green color was because of chlorophyll, mainly because cytokinin has a function in the formation of chlorophyll in the callus and due to environmental factors, such as exposure to light [20]. [21] claimed that the color change in the callus from white to green was due to chlorophyll formation.

\section{Conclusions}

In conclusion, this study indicates that $0.5 \mathrm{ml} / 1 \mathrm{BAP} ; 0.1 \mathrm{ml} / 1 \mathrm{NAA}$ (single PGR); and combination of $0.5 \mathrm{ml} / 1 \mathrm{BAP}+0.1 \mathrm{ml} / 1 \mathrm{NAA}$ (double PGR) can potentially be used to obtain the best callus stimulation from the roots explant source of sengon. The study has also shown that clones had no effect on friable callus formation from root fragments of sengon as explants. Further research needs to be conducted to examine the PGRs for next callus phase of sengon.

\section{References}

1. Larsen, K. Plant resources of South-East Asia Timber trees: major commercial timbers. 1st ed. (eds)., I. Soerianegara, Lemmens RHMJ, editors. Wiley; 2008. 610 p.

2. Chujo, M.; Eizawa, J.; Yokota, S.; Ishiguri, F.; Iizuka, K.; Priadi, D. Micropropagation and protoplast culture in Paraserianthes falcataria. Wood Res J. 2010, 1(2), pp. 108-14.

3. Sumiasri, N.; Priadi, D. Plant propagationof forest tree and its probtem in indonesia:a case study of idustrial forest estates. Bogor; 2004. 
4. Guo, F.; Zhang, H.; Liu, W.; Xingming, H.; Han, N.; Qian, Q. Callus Initiation from root explants employs different strategies in rice and arabidopsis. Plant. Cell. Physiol. 2018. 59(9). pp. 1782-1789.

5. Yu, J.; Liu, W.; Liu, J.; Qin, P.; Xu, L. Auxin control of root organogenesis from callus in tissue culture. Front. Plant Sci. 2018. 8. p. 1385.

6. Hu, B.; Jiang, Z.; Wang, W.; Qiu, Y.; Zhang, Z.; Liu, Y. Nitrate-NRT1.1B-SPX4 cascade integrates nitrogen and phosphorus signalling networks in plants. Nat. Plants. 2019. 5(4). pp. 401-413.

7. Jackson, J.; Dale, P. Callus induction, plant regeneration and an assessment of cytological variation in regenerated plants of Lolium multiflorum L. J. Plant Physiol. 1988. 132(3). pp. 351-355.

8. Singh, C.; Nelson, R.; Subramanian, S.S. Successful plant regeneration from callus culture through organogenesis in Premna Serratifolia L. an important medicinal tree. J. Med. Aromatic Plants. 2011. 2(1). pp. 1-5.

9. Widiyanto, S.; Erytrina, D.; Heni, R. Adventitious shoot formation on teak (Tectona grandis L.f.) callus cultures derived from internodal segments. In: Proc IInd IS on Biotech of Trop E Subtrop Species. 2005. pp. 153-157.

10. Putri, A.I. Microscopic callus selection of sengon tree (Falcataria moluccana) putative tolerant to Uromycladium falcatarium. In: INAFOR IOP Conference Series: Earth and Environmental Science. 2017. pp. 11-15

11. Murashige, T.; Skoog F. A. Revised Medium for Rapid Growth and Bio Assays with Tobacco Tissue Cultures. Physiol. Plant. 1962. 15(3). pp. 473-497.

12. Nieves, M.; Aspuria, E. Callus cultures of Moringa oleifera Lam. Philipp Agric. Sci. 2011. 94(3). pp. $239-247$.

13. Woodward, A.; Bartel, B. Auxin: regulation, action, and interaction. Ann. Bot. 2005. 95(5). pp. 707-735.

14. Ward, K. A.; Jordan, M. Callus formation and plant regeneration from immature and mature embryos of rye (Secale cereale L.). Vitro Cell Dev. Biol. Plant. 2001. 37. pp. 361-368.

15. Franklin, G.; Sheeba, C.; Sita, L. Regeneration of eggplant ( Solanum melongena L.) from root explants. Vitro Cell Dev Biol Plant. 2004. 40(2). pp. 188-191.

16. Jackson, R.; Sperry, J.; Dawson, T. Root water uptake and transport: using physiological processes in global predictions. Elsevier Sci. 2000. 5(11). 482-488.

17. Hossain, A. B. M. S.; Uddin, M. M. Callus cell, shoot and stem proliferation data from pineapple crown and banana inflorescence in vitro: Biochemical and antioxidant properties. Data Br. 2017. p. 10.

18. Afshari, R. T.; Angostari, R.; Kalantari, S. Effects of light and different plant growth regulators on induction of callus growth in rapeseed (Brassica napus L.) genotypes. Plant Omi. J. 2011. 4(2). pp. 60-67.

19. Ikeuchi, M.; Sugimoto, K. I. A. Plant Callus: Mechanisms of induction and repression. Plant Cell. 2013. 25(9). 3159-3173.

20. Chen, Y. M.; Huang, J. Z. ; Hou, T. W. I. Effects of light intensity and plant growth regulators on callus proliferation and shoot regeneration in the ornamental succulent Haworthia. Bot. Stud. 2019. p. 10.

21. Tarrahi, R.; Rezanejad, F. Callogenesis and production of anthocyanin and chlorophyll in callus cultures of vegetative and floral explants in Rosa gallica and Rosa hybrida (Rosaceae). Turk. J. Botany. 2013. 37(6). pp. 145-167. 